\title{
Concise Review of Lead \& Nickel Toxicity impacts on Natural Ecosystem and Human Health
}

\section{$\underline{\text { Authors \& Affiliation: }}$}

1.Devalaraju Ravishankar

2. Vishnumolakala Sridevi

Vananchal Dental College and Hospital, Garhwa, Jharkand.

\section{Corresponding Author}

Devalaraju Ravishankar

ravi_bvrice@gmail.com

Article received: 15.09 .2020

Article accepted: 11.12.2020

(C) 2020.The Authors. Published under

Caribbean Journal of Science and

Technology

ISSN 0799-3757

http://caribjscitech.com/

\begin{abstract}
:
Lead and Nickel are considered as common metal pollutants widely used in alloys, stainless steel, water pipes, cables and batteries etc. Nickel is considered as an essential metal as it is required by the humans and plants at low concentration $(0.001$ to 2.64 micrograms/per day) recommended by United Statespharmacopeial national formulary 2013. In Contrast to Nickel lead is considered as non-essential metal element as it do not have beneficial effect on humans. Boundless usage of these metals entry to the natural ecosystem and reaching in to the human food chain. Accumulation of these metals in to human body on frequent exposure even at low concentration cause serious health hazards or toxicity. Hence we aimed to review lead and nickel toxicity specific to human health, compiling knowledge on Lead and Nickel metals entry to the food chain of humans from the natural ecosystem and summarizing the oxidative stress related to lead and Nickel toxicity.
\end{abstract}

Keywords:Lead, Nickel, Exposure, Health Impacts, Toxicological effects

\section{Need of Review:}

This paper will become a resource of heavy metal toxicity impact on human health for Under graduates, Post graduates as well as for the researchers doing research on heavy metal toxicity as it is covering the information related to the source of metal contamination and various health hazards related to metal pollutants in humans. Excess amount of Heavy metals in the environment contribute to the sustainability and equilibrium of ecosystem processes. Growing information frequently no longer pertains to molecular mechanism of lead and nickel toxicity however it includes the interplay between metal compounds and molecules engaged in cellular events such as multiplication, DNA replication, Protein synthesis and apoptosis. Hence various aspects on lead and nickel toxicity needs to be reviewed up which provide the outline of the problem that could be a global environmental situation.

\section{Introduction:}

Environmental pollution with heavy metal is the serious concern in today world ${ }^{1,2}$. Heavy metal contamination is rapidly increasing since 1940's due to rapid industrialization and urbanization ${ }^{3,4}$. The heavy metals released from industries and due to various human activities enter the food chains cause different health effects in humans on prolonged exposure ${ }^{5}$.The order of metal toxicity in living organisms are $\mathrm{Hg}>\mathrm{Cu}>\mathrm{Zn}>\mathrm{Ni}>\mathrm{Pb}>\mathrm{Cd}>\mathrm{Cr}>\mathrm{Sn}>\mathrm{Fe}>\mathrm{Mn}>\mathrm{Al}^{6-8}$. However the toxicity of the metals do not manifest immediately followed by the exposure and the effects could be observed only at their physiological or biochemical level ${ }^{9}$. The metal concentration in soil influences the microbial life and changes the fertility of the soil ${ }^{10}$. 
The natural ecosystems adversely affected by three means. Microbial population may be vanished in soil at metal concentrations of 1,000 parts per million ( $\mathrm{ppm}$ ) or more, as a result the decomposition process will be slow down. Gradually metal tolerant microbial population increases more in the soil which will change the type of ecosystem present. In all ambientthe lead concentration in the environment can inhibits the normal bio-chemical process (UNEP 1989). Excess usage and non-biodegradable nature of heavy metals increases the metal concentration exponentially. Abundance presence of heavy metal in the ecosystem shows impact on animal and human health. The toxicity, long lasting nature and non-biodegradable properties of heavy metal is becomes a grave and environmental threat in towns and cities ${ }^{11}$.

Exposure of Humans to lead or to its related compounds is occur through various sources such as gasoline, smelting of lead and its combustion in industries, lead based painting, pipes, batteries recycling, grids, pigments, printing press, etc.lead salts (chlorides, bromides, and oxides) released in to the natural ecosystem from car engines due to lead burning. It was published that Lead is one out of four metals that shows the damaging effects on human health ${ }^{12}$ (Table 1).

Widespread use has been demolished in many countries of the world it is still used in many industries like car repair, battery manufacturing and recycling, refining, smelting, etc. Lead affecting almost every organ in the body due to its poisonous nature. The main target of the lead in the human body is the Nervous system, both in children and adults. However the impact of toxicity is greater in children than in adults, due to their tissues, internal as well as external, are softer than in adults. Lead toxicity contributes to behavioral problems, learning deficits and lowered IQ in Infants and young children even at low concentration ${ }^{13}$.

Humans are exposed to nickel constantly due to its abundance presence in the earth crust. Nickel cause a variety of health effects on constant exposure and dose. Various health affects experienced by humans include contact dermatitis, cardiovascular disease, asthma, lung fibrosis, and respiratory tract cancer ${ }^{14}$. The main route for nickel entry is inhalation specifically seen in occupational workers. In non-occupational individuals, nickel enters mainly from stainless steel and nickel-plated articles and cause allergic contact dermatitis ${ }^{15,16}$. However, oral ingestion is the other route of its entry into individuals exposed to contaminated water and food (Table 1$)^{17}$.

Table 1: Lead \& Nickel containing food and items and their toxic effects ${ }^{12,17,18} \& 39$

\begin{tabular}{|l|l|l|l|}
\hline Metal name & Name of the Food material & Name of the item & $\begin{array}{l}\text { Toxic Effect on } \\
\text { human health }\end{array}$ \\
\hline Lead & $\begin{array}{l}\text { Food served in lead containing vessels } \\
\text { or pottery }\end{array}$ & $\begin{array}{l}\text { Lead based painting, pipes, } \\
\text { batteries recycling, grids, } \\
\text { pigments, printing press, etc. } \\
\text { cosmetics ,ceramic glazes, } \\
\text { agricultural waste etc. } \\
\text { abdominal pain and } \\
\text { Hypertension, } \\
\text { coronary artery } \\
\text { disease, } \\
\text { atherosclerosis, } \\
\text { stroke, peripheral } \\
\text { vascular disease, } \\
\text { myocardial infarction } \\
\text { and arrhythmias. } \\
\text { Infertility, menstrual } \\
\text { disorders, abortion } \\
\text { on, stillbirth and } \\
\text { ontrauterine growth } \\
\text { intenal } \\
\text { restriction, renal } \\
\text { disease, anemia etc.. }\end{array}$ \\
\hline
\end{tabular}




\begin{tabular}{|c|c|c|c|}
\hline \begin{tabular}{|l|} 
Nickel \\
\end{tabular} & $\begin{array}{l}\text { Hazelnuts; grains (bran, buckwheat, } \\
\text { millet, whole grain bread, oats, brown } \\
\text { rice, sesame seeds, sunflower seeds); } \\
\text { soya and soya } \\
\text { Products; peanuts; licorice; baking } \\
\text { powder; seafood (shrimps, mussels, } \\
\text { oysters, crab, salmon); cocoa and dark } \\
\text { chocolate; fruits (almonds, dates, figs, } \\
\text { pineapple, } \\
\text { plums, raspberries); vegetables (beans, } \\
\text { savoy cabbage, leeks, lettuce, lentils, } \\
\text { peas, spinach, cabbage), tea from } \\
\text { drinks dispensers }\end{array}$ & $\begin{array}{l}\text { Inexpensive jewelry; eyeglass } \\
\text { frames; cosmetics; keys; paper } \\
\text { clips; cell phones; stainless steel } \\
\text { articles; nickel plated articles; } \\
\text { orthodontic braces; clothing } \\
\text { fasteners (zippers, snap buttons, } \\
\text { belt buckles); metallurgical and } \\
\text { food processing industries; } \\
\text { electrical equipment; armaments; } \\
\text { alloy; pigments; catalysts. }\end{array}$ & $\begin{array}{l}\text { Contact dermatitis; } \\
\text { respiratory } \\
\text { manifestations; lung } \\
\text { cancer; lung fibrosis; } \\
\text { cardiovascular } \\
\text { diseases; headaches; } \\
\text { gastrointestinal } \\
\text { manifestations; } \\
\text { nasal cancer; } \\
\text { epigenetic effects. }\end{array}$ \\
\hline
\end{tabular}

\section{Sources of lead \& nickel pollution:}

In India there are two categories of lead pollution: From Industries the pollutants generated by coal burning and roasting of minerals i.e. iron pyrites, dolomite, alumina etc results in the generation of lead pollutants. From domestic waste lead pollution generated mainly from cooking by means of the solid fuels such as coal, biomass, agriculture waste, paints, and ceramic glazes, cosmetic and fold remedies etc. Lead is purely toxic and is comes under a limited class of elements. Many other essential elements such as chromium, manganese, molybdenum, nickel, and selenium, although toxic at high levels, are literally required nutrients at lower levels. Lead creates major environmental health problem in India at its high rates. Lead is a potent poison even at its low level and is a toxic element showing high metal toxicity in humans and other living organisms. Lead pollution has increased from an estimated 10 tons per year to $1,000,000$ tons per year back from 5000 years ${ }^{18}$.

Nickel is widely distributed in the environment, being generated from two main sources such asnatural sources and anthropogenic activities and add to natural ecosystems like air, water and soil.Natural sources include wind-blown dust, derived during weathering process and soil formation, accidental forest fires etc... Nickel enters air during combustion of biofuel energies like coal, diesel, and other oils. Waste, sewage and miscellaneous incineration also one of the route to add nickel to air ${ }^{19-24}$. Tobacco, dental or orthopedic implants, stainless steelutensils and low cost jewelries are other environmental sources add nickel at low levels ${ }^{25}$. It has been estimated that there is 1.1 to 3.1 microgram of nickel in each cigarette. Some authors stated that, in tobacco smoke nickel is present in the form of nickel carbonyl a hazardous form to man kind ${ }^{26}$.

\section{Sources of Lead Exposure:}

Lead is a common environmental metal toxicant available in three forms: lead Metallic lead salts, and carbon containing organic lead ${ }^{27}$. lead exposure is mainly from industries, infant food and tobacco or cigarette smoking, smoke obtained from coal burning, drinking water pipes and other domestic sources ${ }^{28}$.

UNEP (2010), WHO (2017) stated that occupational exposure is common in individuals who are working in leadacid batteries production units, plumbing, alloys and paints ${ }^{29,30}$. In the work environment, the lead exposure is possible by ingestion and absorption and target the respiratory system and digestive system of humans $\mathrm{s}^{31,32}$ (Figure 1). UNEP (2010) also stated that application and removal of lead containing paints, grinding, welding works and construction and demolition works are the other possible source of lead exposure ${ }^{29}$. Significant sources of lead exposure is possible during recycling of electronic waste, coal mining and smelting.

In the atmosphere, lead will deposit on surfaces or exist for several weeks as a lead component and transport through air as medium in form of aerosols. The aerosols enter the human body during inhalation procedure. The residence of lead in water although differ from the atmosphere ranges from two to five years. The form of lead varies from fresh 
water to sea water. Lead occurs as a bivalent cation $\left(\mathrm{Pb}^{2+}\right)$ in fresh water under acidic condition and forms $\mathrm{PbCO}_{3}$ where as in alkaline condition it forms $\mathrm{Pb}(\mathrm{OH})_{2}$. In sea water the lead form is influenced by the amount of chlorine available hence the form changes from $\mathrm{PbCl}_{3}>\mathrm{PbCO}_{3}>\mathrm{PbCl}_{2}>\mathrm{PbCl}^{+}>$and $\mathrm{Pb}(\mathrm{OH})^{+}$

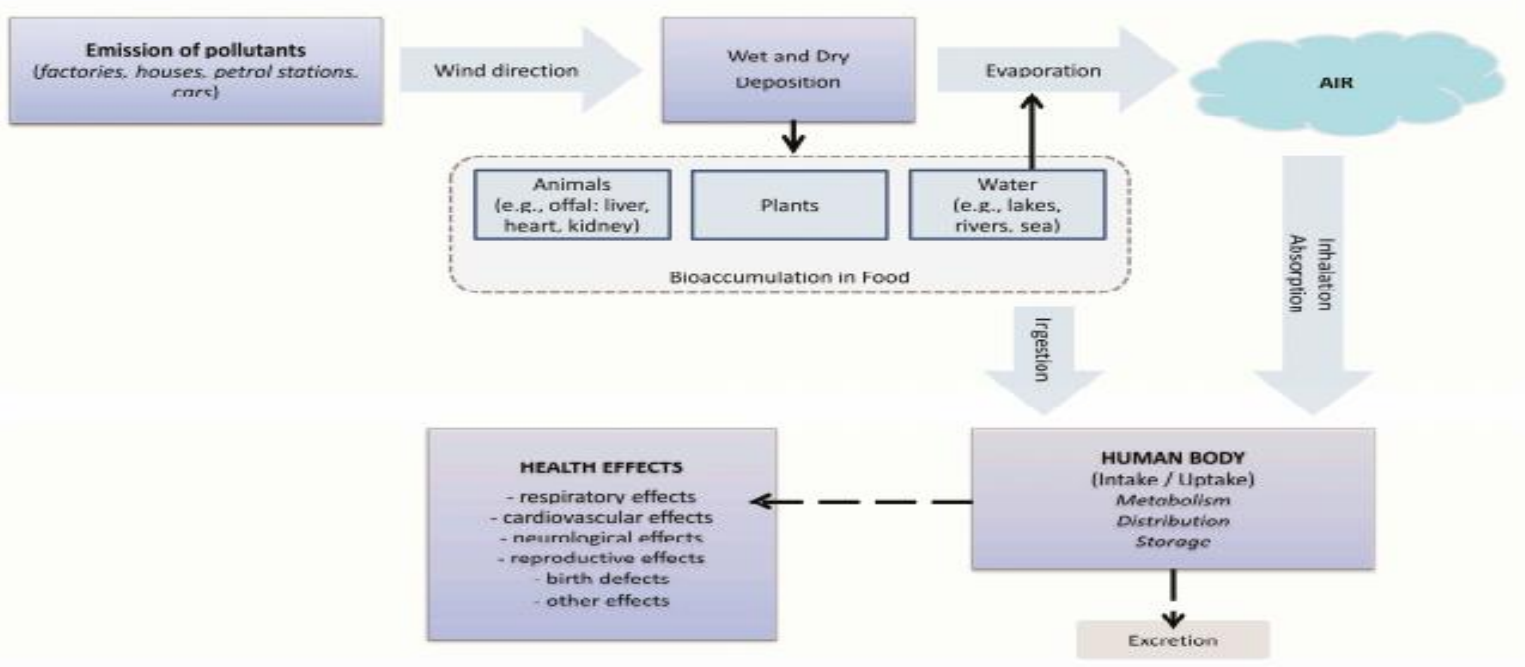

Figure1: Exposure to lead pollution and possible health effects in humans (Adopted from Wani, et al 2015) ${ }^{57}$

In the aquatic environment, the mobility and availability of lead ion varies and is influenced by the type of material to which it is bound for instance lead in its free state i.e. in its ionic form it can mobile highly and is commonly occurring bio-available form in the aquatic environment, lead rather strongly binding with organic complexes with dissolved humus materials the availability is limited, lead upon attached to colloidal particles such as iron oxide strongly the mobility is less compare to its free form. In case of solid particles of clay or dead remains of organisms the lead mobility and availability is bounded.

Source of nickel exposure:The vital source of nickel exposure is food.Breathing air, drinking water, or smoking tobacco containing nickel are also the routes of nickel exposure. Skin contact with soil, bath or shower water, or metals containing nickel, as well as, metals plated with nickel can also result in exposure. According to WHO guidelines 2000 there are three routes of lead exposures: inhalation, ingestion and absorption through skin.

\section{Air:}

$0.1-0.8 \mu \mathrm{g} / \mathrm{day}$ of nickel is inhaled at a respiratory rate of $20 \mathrm{~m}^{3}$ by a normal healthy individual when concentrations are $5-40 \mathrm{ng} / \mathrm{m}^{3}$ in ambient air. Related to particle size and solubility between nickel compounds, there is no evidence on the retention or absorption of nickel in the respiratory tract ${ }^{33}$. By one cigarette smoking there is about $0.04-0.58 \mu \mathrm{g}$ of nickel is released in to the atmosphere $2-23 \mu \mathrm{g}$ of nickel of nickel is inhaled followed by 40 cigarette smoking inhalation ${ }^{34}$.

\section{Drinking-water:}

WHO guidelines 2000 stated that if suppose assuming a concentration of 5-10 $\mu \mathrm{g} /$ litre of water sample, a daily consumption of 2 liters of drinking-water would result in a daily nickel intake of 10-20 $\mu \mathrm{g}$.

\section{Food:}

The nickel content is less than $0.5 \mathrm{mg} / \mathrm{kg}$ fresh weight in most of the food products. However the highest amount of nickel reported in Cacao products and nuts is as much as 10 and $3 \mathrm{mg} / \mathrm{kg}$, respectively ${ }^{35}$. 
Percutaneous absorption: The rate of exposure through percutaneous absorption is relatively at low rates and this exposure usually causes nickel hypersensitivity. The sources of exposure is Iatrogenic route may occur during dialysis procedures, implants, and medication ${ }^{36}$.

Storage of Lead in the Body: Lead is stored in the bones (Fernando, 2005) where it is not uniformly distributed and tends to accumulate in bone regions undergoing the most active calcification at the time of exposure. Accumulation occurs mainly in the trabecular bone during childhood and in the cortical bone in adulthood. Mobilization of lead increases from bone to blood and is related with various factors such as age, chronic disease conditions like arthritis, physiologic stress, hyperthyroidism, kidney disease, pregnancy and lactation. Lead mobilization is very rapid at these conditions in humans specified by: (Agency for Toxic Substances and Disease Registry.2017) ${ }^{37}$.

- Pregnancy and lactation

- Periods of physiologic stress

- Hyperthyroidism- Chronic disease

- Kidney diseases- Chronic disease

- Menopause

- Advanced age

Nickel storage in the human body:

Early to 2016 many references, it is specified that nickel is stored in kidney, liver and in lungs. In contrast to this recently it was stated. Currently there are no new specified determination and evaluation of reference in which nickel values would appear. The author mentioned that recently available literature on nickel content in human body mostly concerns the material which can be easily obtained from biomaterials, such as blood, urine and hair ${ }^{38}$.

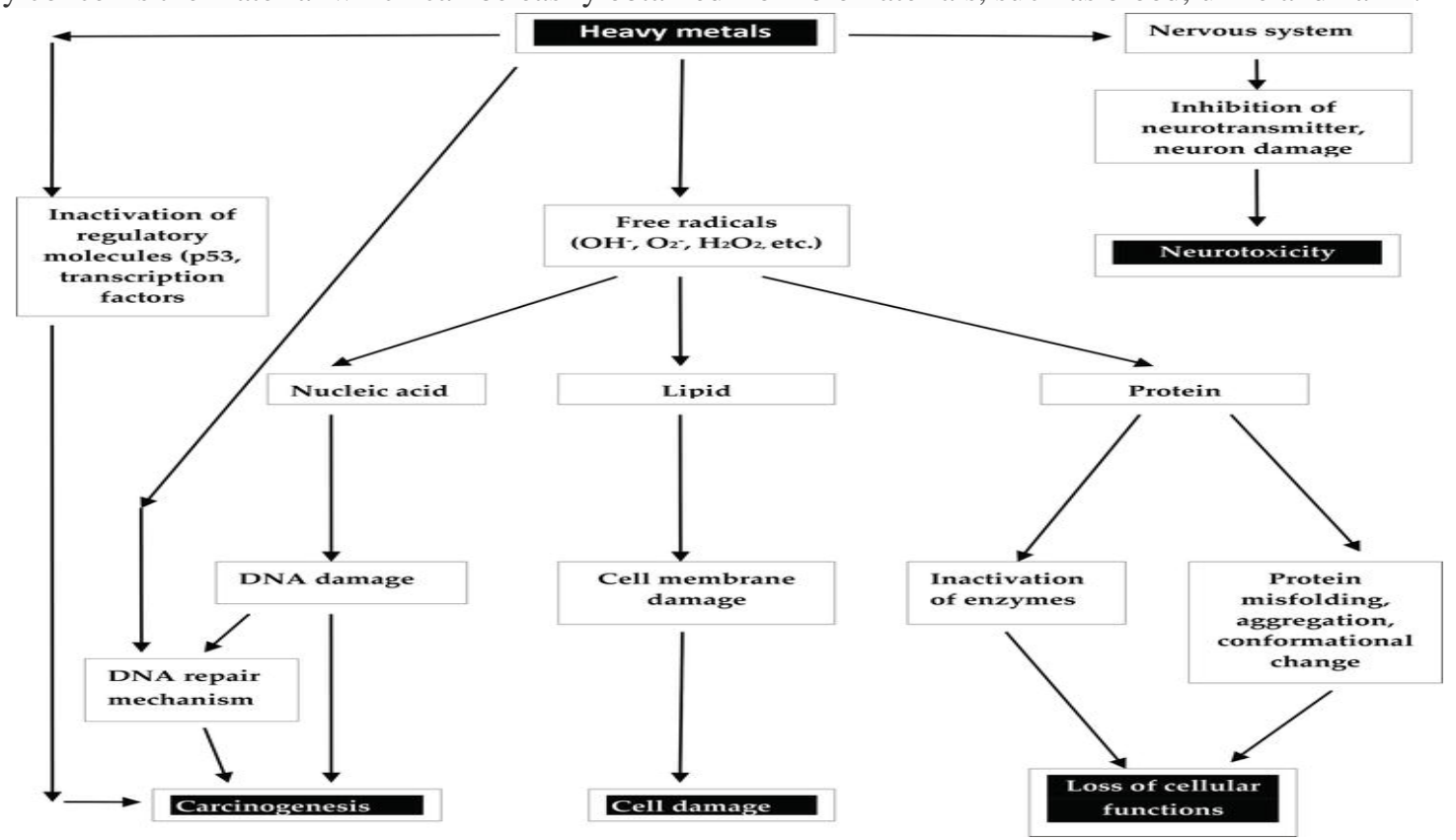

Figure 2: Pathway of heavy metals sources and exposure to humans.

\section{Vulnerable age group:}

Agency for Toxic Substances \& Disease Registry, 2016 reported that Fetus, Infant and Child are most vulnerable groups. Compare to adults the fetus and child are more sensitive to lead exposures. The target of lead is brain and nervous system. In Children lower blood levels were reported followed by lead exposure compare to adults. Lead impact is high in developing fetus with minor health issues in mother ${ }^{39}$. 
Agency for Toxic Substances \& Disease Registry, 2016 reported that similar health effects will be seen both in children and in adults. There is no evidence of susceptibility nature of children differ from adults to nickel exposure. There is inclusive evidence on the effect of nickel on fetus development. However increased levels of nickel in newborn deaths and decreases in newborn weight after ingesting nickel were reported by animal studies.

It is probably that nickel can reach the infant from mother through breast milk and placenta. There are similar nickel levels in cow's milk-based or soy-milk-based infant formula like in breast milk were reported ${ }^{40}$. Females is more sensitive to nickel than men. This differences in vulnerability between female and male is due to the result of greater exposure of females to nickel through jewellery and other metal items.

\section{Health Impacts of Lead:}

Lead toxicity can impact several systems in the human body even at low level of exposuresaccording to the report released by Agency for Toxic Substances \& Disease Registry, $2016^{39}$.

Gastrointestinal system- severe cramping and abdominal pain inrisk conditions.

Cardiovascular system- lead exposure encounter the development of hypertension, coronary artery disease, peripheral vascular disease, atherosclerosis, stroke, myocardial infarction (heart attack) and arrhythmias.

Reproductive system- affect the sperm morphology, mobility, fertility, time to sexual maturation, menstrual disorders and labor related issues such as abortion, stillbirth and intrauterine growth restriction, poor growth developments in children.

* Renal system- chronic advanced renal disease or renal impairment.

* Circulatory system-inhibition of hemoglobin formation and cause anemia.

* Endocrine system-making the body to unfit in the conversion of vitamin D into its hormonal form.

* Causing opacification of the lens of the eye which leads to decrease in vision ultimately results incataracts.

* Skeletal system- bone deformation, arthritisleads to gout.

* Immune system- humans exposed to lead suffer with immune suppression.

* Nervous system- The main sensitive target of lead exposure, this system includes the brain.

According to Martin \& Griswold, 2009, lead toxicity may be acute or chronic. Acute toxicity include loss of appetite, headache, hypertension, abdominal pain, renal dysfunction, fatigue, insomnia, arthritis, illusions and dizziness. Acute exposure mainly occurs in the work places and in some industries working with lead metals and its speciation. Chronic toxicity upon chronic exposure leads to amentia, congenital abnormalities, mental illness, nervous breakdown, allergies, reading disorders called dyslexia, weight loss, hyperactivity, paralysis, muscular weakness, brain damage, renal damage and may even fatal ${ }^{41}$.

Kosnett, 2005; well-studied the effects of lead at cellular level damage the cell structures, including DNA and cell membrane by the formation of reactive radicles. It also inhibits vitamin D biosynthesis by interfering with the enzymes involved in the synthesis of vitamin D. Also lead inhibits the enzymes that maintain the integrity of the cell membrane and DNA transcription ${ }^{42}$.

The effects were explained and showed in Figure 3. 


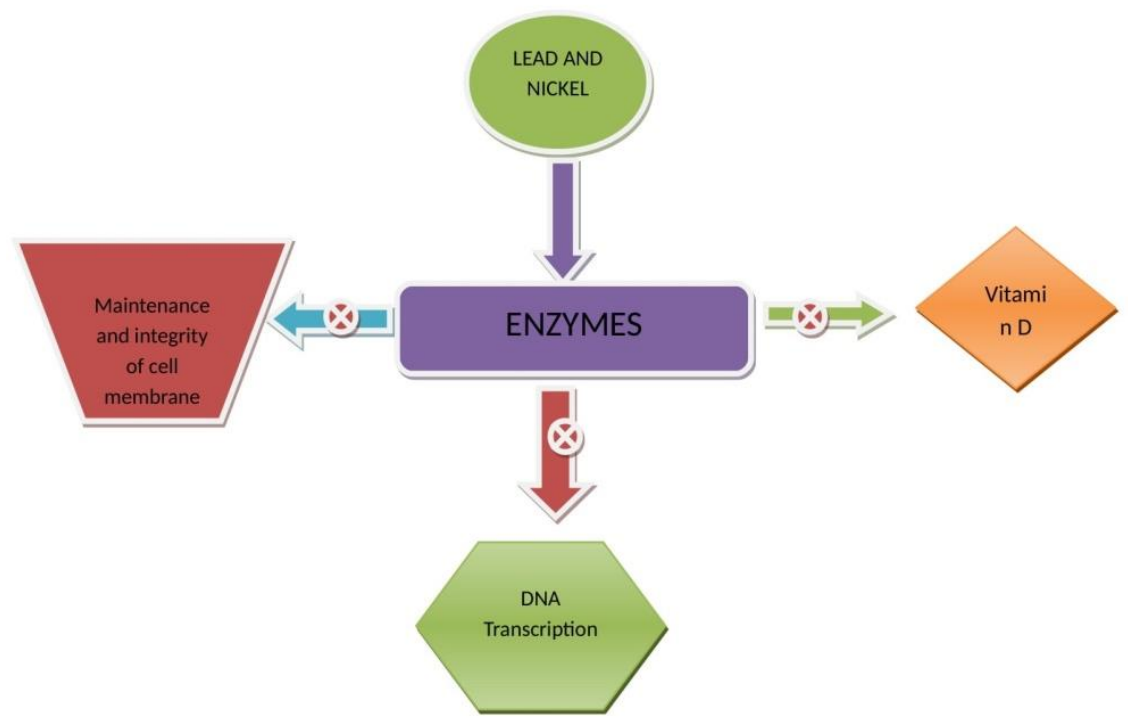

\section{Figure 3: Illustration of the action of lead on enzymes, leading to the disruption of vitamin $D$ synthesis, maintenance of cell membrane and DNA transcription ${ }^{42}$.}

Patrick et al. 2006 and Fujita et al.2002reported that lead by interfering with a key enzyme namely deltaaminolevulinic acid dehydratase (ALAD) for the biosynthesis of heme ( the cofactor found in hemoglobin) causes anemia $^{43,44}$.

Dart et al., 2004 stated that the lead levels usually at equal amount it is transferred from mother to fetus mediated by placenta and mother's milk, hence the lead level in the blood of mother is same as in fetus blood lead level ${ }^{45}$.

Navas-Acien et al. 2007 stated that in males lead exposure affect the sterility, general morphology of sperm, sperm count and its mobilityand Park et al. 2008 studies reported that lead exposurein femalesthereare more severe labor concern problems such as miscarriages, prematurity, low birth weight, and improper development during childhood $^{46,47}$.

Zhang et al. (2014), in a recent studied it was reported that in human chronic gonadotropin (HCG) is common by lead interactions. There is change in the secondary structure of HCG was investigated by UV-vis absorption spectroscopy, circular dichroism spectroscopy, and ELISA. These investigations revealed that lead acetate decreasing the bioactivities of HCG by changing the secondary structure of HCG increases the hydrophobicity development around the Tyr residues resulted in loosening and destruction of the HCG skeleton ${ }^{48}$.

Mere boiling methods are not proven as sufficient methods in lead removal instead boiling always enhances the lead quantity hence it is recommended by the researchers that there are number of water purification methods are available which are proven as successful effective treatment procedures in lead removalsuch as R.O treatment, Distillation, filtration procedure using specialized filters (Undersink filters, Countertop filters, Faucet filters) (Minnesota Department of Health, 2010) ${ }^{49}$.

Health impacts on Nickel: Nickel exposure can show serious impact on human healthaccording to the report released by Agency for Toxic Substances \& Disease Registry, 2005 ${ }^{40}$ are discussed below:

Allergic reaction is the usual harmful health effect in humans.

It was estimated that roughly $10-20 \%$ of the population is sensitive to nickel.

The sensitized people on direct contact of nickel containing jewelleries suffer with skin rashes at the contact site. In some sensitized individuals hand eczema (a type of skin rash) developed on nickel contact. 
Some of the sensitized individuals experienced with asthma upon nickel inhalation.

Occupational exposure to nickel through water with a concentration of $200 \mathrm{ppm}$ causes serious stomach pain increased RBC level a serious blood effect and also kidney related diseases in workers.

Respiratory problems associated with nickel inhalation include chronic bronchitis, reduced lung function, and lung cancer and sinus.

Nickel and its speciation are known to be human carcinogens causes cancer on nickel exposure at higher rates.

In humans oral exposure to high levels of soluble nickel compounds through the environment is uncommon. It is due the fact that exposure to high level of nickel through water or food is extremely rare.

The European Union classification, classified many soluble and insoluble nickel compounds as Carc1A a potential human carcinogens under Labelling and Packaging legislation ${ }^{50}$.

Similarly the International Agency for Research on Cancer (IARC) categorized nickel and its compounds under two groups such as nickel compounds under group 1 and nickel and alloys under group 2B carbonic compounds to mankind ${ }^{51}$.

Lee, J.E et al. 1982, andBiggart et al. 1986 stated that Nickel ions interact weakly with DNA and strongly interact with proteins. For example, $\mathrm{Ni}^{2+}$ has bindingconstants of $6.7 \times 10^{-1} \mathrm{M}^{-1}$ for adenosine (nucleic acid) whereas $4.37 \times$ $10^{9} \mathrm{M}^{-1}$ with cysteine ${ }^{52,53}$, there is no direct genotoxic effect related to nickel and nickel compounds.

I contrast nickel and nickel compounds acts as Indirect genotoxicants can damage DNA via secondary mechanisms like generation of reactive oxygen species (ROS) or inhibition of DNA repair mechanisms by competitively inhibiting repair enzyme called $\mathrm{ABH}_{2}$.

Nickel and nickel compounds form oxygen free radicals and cause DNA damage indirectly it enhances the formation of DNA-Protein crosslinks. Nickelcompounds can enhance histone phosphorylation (H3S10), methylation (H3K4), ubiquitination (H2Band H2A) and decrease histone acetylation (H4) by inhibiting the action of histone acetyltransferase activity. Zhang et al. 2013 and Yang et al. 2013 cited that non-coding RNAs play a rolein nickel respiratory carcinogenesis ${ }^{54-57}$.

\section{Conclusion:}

Metal toxicity is a serious concern, causes severe health hazards in humans and can be preventable by following significant preventable measures. The mandatory approach to avoid lead toxicity is avoidance of any possible exposure to lead this can be achieved by creating awareness to the occupational and non-occupational population on lead sources in the environment and proper removal of disposed waste achieved by bioremediation. The hazardous health effects related to metal toxicity is occur in the central and peripheral nervous systems, the hematopoietic system, the cardiovascular system and in some organs such as the liver and kidneys. Review on metal toxicity and removal of metal pollution should promote awareness on health hazards related to metal exposure, increase health knowledge and provide various bioremediation strategies necessary to prevent metal pollutants from the natural ecosystem. Notably Oxidative stress related to lead is treatable by antioxidants, particularly vitamin $\mathrm{C}$ so far. Avoidance of low cost jewelry is highly recommended to avoid nickel toxicity. Periodical health checkups and awareness on source of metal contamination and its toxicity are vital elements in the avoidance of metal toxicity among mankind.

\section{References:}

1. Ali, H., Khan, E., Sajad, M.A. (2013). Phytoremediation of heavy metals-Concepts and applications. Chemosphere, 91 (7): 869-881. 
2. Hashem, M.A., Nur-A-Tomal, M.S., Mondal, N.R., Rahman, M.A. (2017). Hair burning and liming in tanneries is a source of pollution by arsenic, lead, zinc, manganese and iron. Environ. Chem. Lett, 15 (3):501-506.

3. Khan, F.U., Rahman, A.U., Jan, A., Riaz, M. (2004). Toxic and trace metals (Pb, Cd, Zn, Cu, Mn, Ni, Co and $\mathrm{Cr}$ ) in dust, dustfall/soil. J. Chem. Soc. Pakistan, 26 (4): 453-456.

4. Merian, e. (1984). Introduction on environmental chemistry and global cycles of chromium, nickel, cobalt beryllium, arsenic, cadmium and selenium, and their derivatives. Toxicol. Environ. Chem, 8 (1): 9-38.

5. Wieczorek-Da browska, M., Tomza-Marciniak, A., Pilarczyk, B., Balicka-Ramisz, A. (2013). Roe and red deer as bioindicators of heavy metals contamination in north-western Poland. Chem Ecol, 29 (2):100-110.

6. Wang, Q., Cui, Y., Liu, X., Dong, Y., \& Christie, P. (2003). Soil contamination and plant uptake of heavy metals at polluted sites in China. Journal of Environmental Science and Health, Part A, 38:823-838.

7. Pueyo, M., Lopez-Sanchez, J. F.,\&Rauret, G. (2004). Assessment of $\mathrm{CaCl} 2, \mathrm{NaNO} 3$, and $\mathrm{NH}_{4} \mathrm{NO}_{3}$ extraction procedures for the study of $\mathrm{Cd}, \mathrm{Cu}, \mathrm{Pb}$ and $\mathrm{Zn}$ extractability in contaminated soils. Analy. Chim. Acta, 504: 217-225.

8. Filipiak-Szok, A., Kurzawa, M., \&Szlyk, E. (2015). Determination of toxic metals by ICP-MS in Asiatic and European medicinal plants and dietary supplements. J. Trace Elem. Med. Biol, 30:54-58.

9. Wojciechowska-Mazurek, M., Starska, K., Brulińska-Ostrowska, E., Plewa, M., Biernat, U., Karłowski, K. (2008). Monitoring of contamination of foodstuffs with elements noxious to human health. Part I. Wheat cereal products, vegetable products, confectionery and products for infants and children (2004 year). Rocznik PZH, 59:251-266.

10. Barbieri, M. (2016). Importance of enrichment factor (EF) and geoaccumulation index (Igeo) to evaluate the soil contamination. J. Geol. Geophys, 5 (1):237.

11. Baatrup, E. (1991). Structural and functional effects of heavy metals on the nervous system, including sense organs, of fish. Comp. Biochem. Physiol. C. Toxicol. Pharmacol, 100 (1-2):253-257.

12. Tiwari, S., Tripathi, I.P. (2012). Lead Pollution -An Overview, Int. Res. J. Environment Sci., 1(5):84- 86.

13. Rubin, R., Strayer, D.S. (2008). Rubins pathology; Clinicopathologic Foundations of Medicine. $5^{\text {th }}$ ed. Lippincot Williams \& Wilkins; Environmental and Nutritional pathology.

14. Chen, Q.Y., Brocato, J., Laulicht, F., Costa, M. (2017). Mechanisms of nickel carcinogenesis. In Essential and Non-Essential metals. Molecular and Integrative Toxicology; Mudipalli, A., Zelikoff, J.T., Eds.; Springer International Publishing AG: New York, NY, USA, pp. 181-197.

15. Sinicropi, M.S., Caruso, A., Capasso, A., Palladino, C., Panno, A., Saturnino, C. (2010). Heavy metals: Toxicity and carcinogenicity. Pharmacologyonline, 2: 329-333.

16. Sinicropi, M.S., Amantea, D., Caruso, A., Saturnino, C. (2010). Chemical and biological properties of toxic metals and use of chelating agents for the pharmacological treatment of metal poisoning. Arch. Toxicol, 84:501-520.

17. Sinicropi, M.S., Rovito, N., Carocci, A., Genchi, G. (2012). Acetyl-L-carnitine in Parkinson's disease. In Mechanisms in Parkinson's disease-Models and Treatments; Dushanova, J., Ed.; InTech: London, UK, Chapter 19; pp. 367-392.

18. Davidson, C.L., Rabinowitz, M. (1992). Lead in the Environment, from sources to human receptors, In: Needleman H .ed. Human Lead Exposure. Boca Raton, F L: CRC Press.

19. Clayton, G.D., Clayton, F.E. (1994). Patty's Industrial Hygiene Toxicology, 4th ed.; A Wiley-Interscience Publication: New York, pp 2157-2173.

20. Grandjean, P. (1984). Human exposure to nickel. IARC Sci. Publ, 53:469.

21. Clarkson, T.W. (1988). Biological Monitoring of Toxic Metals; Plenum Press: New York, pp 265-282.

22. Environmental Health Criteria 108. (1991). Nickel. WHO, Genewa.

23. Von Burg, R. (1997). Toxicology update. J. Appl. Toxicol, 17: 425.

24. Spectrum. (1998). Chemical Fact Sheet. Nickel. Website: http://www.speclab.com/elements/nickel.htm.

25. Colloidal Minerals. (1992). Nickel. Web site: http://www.eagle-min.com/faq/faq 101.htm

26. Environmental Health Criteria 108. (1991). Nickel. WHO, Genewa. 
27. Assi, M.A., Hezmee, M.N.M., Haron, A.W., Sabri, M.Y., Rajion, M.A. (2016). The detrimental effects of lead on human and animal health. Vet. World, 9(6): 660-671.

28. Thürmer, K., Williams, E., Reutt-Robey, J. (2002). Autocatalytic oxidation of lead crystallite surfaces. Science, 297(5589):2033-2035.

29. UNEP (2010). Final review of scientific information on lead. Nairobi, United Nations Environment Programme, Chemicals Branch.

30. WHO (2017). Recycling used lead-acid batteries: health considerations. Geneva, World Health Organization.

31. Spivey, A. (2007). The Weight of Lead: Effects Add Up in Adults. Environ. Health Perspect, 115:30-36.

32. ATSDR. (2017). Lead Toxicity: Case Studies in Environmental Medicine (CSEM). Environmental Health and Medicine Education. Available online: https://www.atsdr.cdc.gov/csem/lead/docs/CSEMLead_toxicity_508.pdf.

33. Oberdörster, G. (1992). Lung dosimetry: extrapolation modeling from animals to man. In: Nieboer, E. \& Nriagu, J.O., ed. Nickel and human health: current perspectives. New York, Wiley, pp. 421-436.

34. Nickel. (1991). Geneva, World Health Organization, (Environmental Health Criteria, No.108).

35. Nickel and nickel compounds. (1990). In: Chromium, nickel and welding. Lyon, International Agency for Research on Cancer, pp. 257-445.

36. Mushak, P. (1980). Metabolism and systemic toxicity of nickel. In: Nriagu, J.O., ed. Nickel in the environment. New York, Wiley, pp. 499-524.

37. Agency for Toxic Substances and Disease Registry. (2017). Environmental Health and Medicine Education. Lead Toxicity: What is the Biological Fate of Lead?.

38. Zober, A., Kick, K., Schaller, K.H., Schellmann, B., Valentin, H. (1984). Nickel and chromium content of selected human organs and body fluids. Zentralbk. Bakteriol. Mikrobiol. Hyg BG, 179(1):80-95.

39. Agency for Toxic Substances \& Disease Registry. (2016). Lead Toxicity: What Are the Physiologic Effects of Lead Exposure?.

40. Agency for Toxic Substances and Disease Registry (ATSDR). (2005). Toxicological profile for Nickel. Atlanta, GA: U.S. Department of Health and Human Services, Public Health Service.

41. Martin, S., Griswold, W. (2009). Human health effects of heavy metals. Environ. Sci. Technol. Brief. Citizens, 15: 1-6.

42. Kosnett, M.J. (2005). Lead. In: Brent J, editor. Critical Care Toxicology: Diagnosis and Management of the Critically Poisoned Patient. Gulf Professional Publishing.

43. Patrick, L. (2006). Lead toxicity, a review of the literature. Part 1: Exposure, evaluation, and treatment. Altern. Med. Rev, 11:2-22.

44. Fujita, H., Nishitani, C., Ogawa, K. (2002). Lead, chemical porphyria, and heme as a biological mediator. Tohoku. J. Exp. Med, 196(2):53-64.

45. Dart, R.C., Hurlbut, K.M., Boyer-Hassen, L.V. (2004). Lead. In: Dart, R.C., editor. Medical Toxicology. 3rd ed. Lippincot Williams and Wilkins.

46. Navas-Acien, A., Guallar, E., Silbergeld, E.K., Rothenberg, S.J. (2007). Lead Exposure and Cardiovascular Disease--A Systematic Review. Environ. Health Perspect, 115:472-482.

47. Park, S.K., O’Neill, M.S., Vokonas, P.S., Sparrow, D., Wright, R.O., Coull, B., Nie, H., Hu, H., Schwartz, J. (2008). Air Pollution and Heart Rate Variability: Effect Modification by Chronic Lead Exposure. Epidemiology, 19:111-120.

48. Zhang, H., Liu, Y., Zhang, R., Liu, R., Chen, Y. (2014). Binding Mode Investigations on the Interaction of Lead (II) Acetate with Human Chorionic Gonadotropin. J. Phys. Chem. B, 118:9644-9650.

49. Minnesota Department of Health. (2010). Point-of-Use Water Treatment Units for Lead Reduction.

50. European Chemicals Agency (ECHA). (2018). Classification, Labelling and Packaging. Table of Harmonized Entries inAnnex VI to CLP; European Chemicals Agency: Helsinki, Finland.

51. International Agency for Research on Cancer (IARC). (2012). Nickel and nickel compounds. IARC Monogr. Eval. Carcinog. Risks Hum, 100C:169-218. 
52. Lee, J.E., Ciccarelli, R.B., Jennette, K.W. (1982). Solubilization of the carcinogen nickel subsulfide and its interactionwith deoxyribonucleic acid and protein. Biochemistry, 21: 771-778.

53. Biggart, N.W., Costa, M. (1986). Assessment of the uptake and mutagenicity of nickel chloride in Salmonella testerstrains. Mutat. Res, 175: 209-215.

54. Zhang, J., Zhou, Y., Ma, L., Huang, S., Wang, R., Gao, R., Wu, Y., Shi, H., Zhang, J. (2013). The alteration of miR-222and its target genes in nickel-induced tumor. Biol. Trace Elem. Res, 152: 267-274.

55. Zhang, J., Zhou, Y., Wu, Y.J., Li, M.J., Wang, R.J., Huang, S.Q., Gao, R.R., Ma, L., Shi, H.J., Zhang, J. (2013). Hyper-methylated miR-203 dysregulates ABL1 and contributes to the nickel-induced tumorigenesis. Toxicol. Lett, 223:42-51.

56. Ji, W., Yang, L., Yuan, J., Yang, L., Zhang, M., Qi, D., Duan, X., Xuan, A., Zhang, W., Lu, J. (2013). MicroRNA-152targets DNA methyltransferase 1 in NiS-transformed cells via a feedback mechanism. Carcinogenesis, 34: 446-453.

57. Wani, A.L, Usmani, J. A. (2015). Lead toxicity: A review. Int. Toxicol, 8:55-64. 